\title{
Wastewater electrooxidation using stainless steel electrodes
}

\author{
Nicoleta Ungureanu ${ }^{1}$, Valentin Vlăduțt, ${ }^{2}$, , Mario Cristea ${ }^{2}$ and Dan Cujbescu ${ }^{2}$ \\ ${ }^{1}$ University Politehnica of Bucharest, Department of Biotechnical Systems, Splaiul Independentei nr. \\ 313, sector 6, Romania \\ ${ }^{2}$ National Institute of Research - Development for Machines and Installations Designed to \\ Agriculture and Food Industry - INMA Bucharest, Ion Ionescu de la Brad nr. 6, sector 1, Romania
}

\begin{abstract}
Wastewater contains essential nutrients for crops, and after proper treatment its reuse is beneficial to farmers in arid and semi-arid areas. Electrooxidation is an environmentally friendly technology used for treatment of domestic, industrial and agrozootechnical wastewater. During electrooxidation, organic compounds are oxidized at the interface between the anode and the aqueous solution, as a result of the reduction reaction at the cathode. Tests were performed on wastewater collected from the lagoon of a cattle farm, using an electrooxidation cell with stainless steel electrodes. The removal of $\mathrm{pH}$, conductivity, turbidity, color, total $\mathrm{N}$, total $\mathrm{P}, \mathrm{COD}$ and BOD was investigated at specific voltages of $0.025 \mathrm{~V} \mathrm{~cm}^{-2}$, $0.05 \mathrm{~V} \mathrm{~cm}^{-2}$ and $0.1 \mathrm{~V} \mathrm{~cm}^{-2}$ and various electrolysis times $(15,30,60$ and 120 minutes). Results show that electrooxidation is effective in reducing total $\mathrm{N}$ by $24 \%$, total P by $47 \%$, BOD by $47 \%$ and COD by $82 \%$. After completion of tests, the suspended solids were decanted towards the anode area, due to the action of coagulant $\mathrm{Fe}_{2}{ }^{+} / \mathrm{Fe}_{3}{ }^{+}$ions formed by anode dissolution, and the water was clarified. The effluent complies with the standards to be reused to irrigate crops tolerant to salinity grown in permeable soils.
\end{abstract}

\section{Introduction}

In 2019 water scarcity has affected over $17 \%$ of Europe's territory and over $11 \%$ of its population [1]. Food and Agriculture Organization of the United Nations estimates that by 2050 , the global food production will have to increase by at least $50 \%$ to feed 9 billion people [2]. Agriculture consumes about $70 \%$ of freshwater, so the sustainable use of water resources is vital.

Wastewater reuse in irrigated agriculture became an important component in agricultural water supply in many water-scarce countries [3]. The reuse of wastewater in agriculture is part of water resource development and management that provides innovative and alternative options for agriculture, if the wastewater is properly treated to ensure that it has no harmful effects to human health or the environment.

Even in developed countries or in those not yet affected by water shortage, wastewater reuse for irrigation is a common practice. At present, over 15 million $\mathrm{m}^{3} \mathrm{day}^{-1}$ of treated

* Corresponding author: valentin vladut@yahoo.com 
water are used for irrigation of crops worldwide. The European countries reuse 1 billion $\mathrm{m}^{3}$ year $^{-1}$ of treated urban wastewater, which is $2.4 \%$ of the treated urban wastewater effluents [4]. Thus, at least $10 \%$ of global population consumes food from crops grown by wastewater reuse [5].

Many countries have national regulations that prohibit the irrigation of agricultural crops with raw wastewater and impose limits for different physico-chemical and bacteriological parameters, including wastewater turbidity, $\mathrm{pH}$, electrical conductivity, heavy metals, suspended solids, BOD, COD, nutrients, pathogenic bacteria, fecal coliforms, fecal enterococci and nematode eggs [6].

The evaluation of the possibility of reusing treated wastewater involves the qualitative analysis of the wastewater in close connection with the characteristics of soil, the type of crop and the necessary irrigation norms.

Treated wastewater from cattle farms can be used for irrigation, thus benefiting from their high content of organic substances and nutrients (nitrogen and phosphorus), but their soluble salt content requires mixing them with conventional clean water or applying low quality standards, suitable only to crops tolerant to salinity and on soils with suitable drainage.

The electrochemical treatment of wastewater is a technology that uses a constant voltage applied on a pair of metal plates (electrodes) immersed in a basin containing wastewater, to decompose partially or completely the organic pollutants. This type of treatment is classified as an advanced treatment and requires other pretreatments. On the other hand, the efficiency of electrooxidation as wastewater pretreatment depends on the anodes used to mediate the organic species oxidation present in the wastewater [7].

Electrochemical methods, including the oxidation of organic pollutants by cathodic generation of hydrogen peroxide, cathodic removal of metals, anodic oxidation using electrodes made of different materials and shapes, and electrocoagulation, are effective in the oxidative degradation of many organic pollutants in wastewater [8].

Electrooxidation is an electrochemical advanced oxidation process which involves electrolytic reactions at the electrodes surface, the formation of anodic metal and metal hydroxide cations in aqueous phase, the adsorption of soluble or colloidal pollutants on the surface of metal hydroxides, and the removal of organic pollutants by electroflotation, sedimentation and adhesion to the bubbles. Metal hydroxide precipitation is influenced by the $\mathrm{pH}$ of wastewater.

Different shapes, configurations and materials have been used so far for the electrodes. In terms of shape, rectangular vertical plates and pipes are widely used, connected either as monopolar-parallel (MP-P), monopolar-series (MP-S) or bipolar-series (BP-S), as shown in Figure 1 [9].

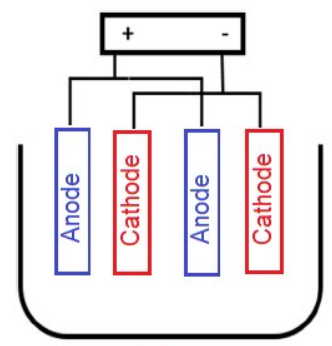

MP- $P$

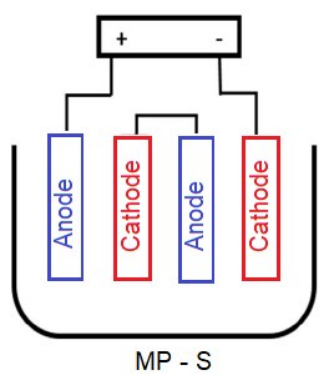

MP - S

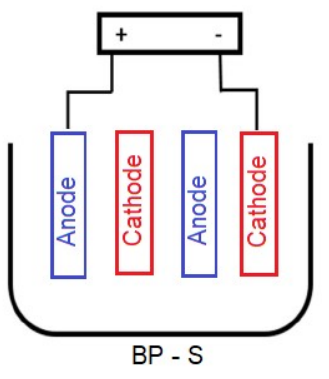

$B P-S$

Fig. 1. Possible electrode connections in electrolysis cells for wastewater treatment [9]

Aluminum, iron, titanium, stainless steel, magnesium, graphite, boron-doped diamond for thin-film anodes, lead dioxide, tin oxide, platinum are only some of the non-hazardous, 
available materials for the manufacture of electrodes, and they have shown good removal rates of organic pollutants from wastewater.

The electrocatalytic properties of anodic materials have an important role in the removal efficiency of organic pollutants by electrooxidation [10].

Like all electrochemical treatments of wastewater, electrooxidation can take place with complete automation of the process, without direct addition of chemical reagents [11] because the electron itself acts as reagent which allows the agglomeration of pollutants; electrooxidation does not generate secondary pollution (which occurs in traditional chemical methods due to high concentration of chemicals), hence electrooxidation has an reduced impact on the environment.

Although electrooxidation is especially efficient in removing COD from wastewater, it is a process that generates significant quantities of sludge [12]. Another drawback of wastewater electrooxidation is the corrosion and consumption of the electrodes [13]. In time, an impermeable oxide layer is formed on the cathode, especially when Al electrodes are used. This layer slows the transmission of current within the electrolysis system, resulting in higher power consumption, higher costs and lower treatment efficiency [14]. To prevent electrodes passivation and the sediment deposits on their surface, electrodes polarity should be changed at regular intervals of time [15] or they must be replaced regularly for enhanced treatment efficiency.

To increase the efficiency of electrooxidation, wastewater containing high amounts of suspended solids must be first treated to remove the solids. For example, coupled electrocoagulation (using $\mathrm{Al}, \mathrm{Fe}$ or $\mathrm{Al} / \mathrm{Fe}$ electrodes) - electrooxidation processes are increasingly used. Electrocoagulation removes the finest colloidal particles in wastewater because the applied electric current fastens their collision and facilitates the coagulation.

\section{Material and method}

Experimental research was conducted on wastewater originated from a medium-sized cattle farm in Romania. The environmental practices according to which the farm operates involve collecting and storing the wastewater in a waterproofed lagoon provided with a mechanical stirring system (Figure 2) until its application on farmland as fertilizer.

Wastewater produced in the cattle farm is actually a mixture of wastewater from paddock scrubbing, liquid manure mixed with entrained solid residues, wastewater from milk processing on the farm's milk factory, and meteorological waters.
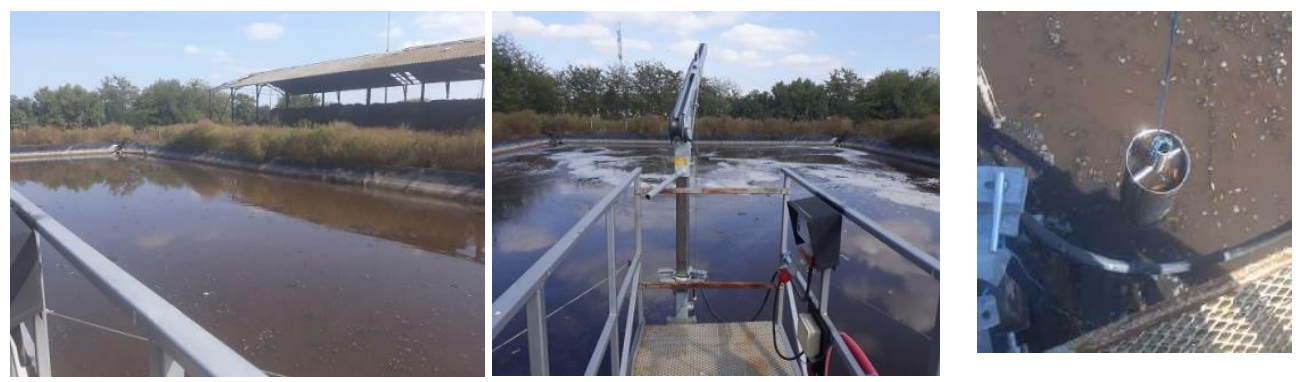

Fig. 2. Lagoon for wastewater storage, mechanical stirrer and wastewater sampling

The main organic pollutants in these effluents are manure and forage entrained by liquid, carbohydrates, proteins and fats originating from the farm's dairy factory. The coarse residues of organic nature represented by animal manure, forage residues and paddock litter are collected and stored on a composting platform. 
Storing the wastewater in the lagoon favors the achievement of extensive local treatment, in which the wastewater is initially subjected to a physical treatment of gravitational separation of coarse impurities (clarification), and also to aerobic-anaerobic biochemical processes in which the organic substances are reduced. The stirrer increases the oxygen supply in the wastewater mass, thus contributing to the improvement of the degradation of organic substances.

During sampling, the wastewater collected in the lagoon was continuously stirred to train the solid particles deposited on the bottom. The general rules for sampling of wastewater are included in the standard SR ISO 5667-10/1994.

In electrochemical wastewater treatment, electricity is employed to conduct electrolysis processes in which the decomposition of some substances and the formation of new products at the electrode by means of electric current take place. In electrolysis, pollutants removal can be achieved by direct oxidation in the electrode process (anodic oxidation), by indirect oxidation with strongly oxidizing products resulting at the anode $\left(\mathrm{O}_{2}\right.$ and $\left.\mathrm{Cl}_{2}\right)$ and by electrochemical coagulation.

The equipment used for the treatment of wastewater by electrochemical oxidation consists of an electrochemical cell (Plexiglas basin, $500 \times 200 \times 200 \mathrm{~mm}$ ), in which was placed a pair of electrodes linked to a voltage source that supports a continuous current of maximum $5 \mathrm{~A}$, and an apparatus for measuring the energy consumption (Figure 3). The electrodes were made of parallel stainless steel pipes (12 mm diameter, $200 \mathrm{~mm}$ length) with both ends welded on stainless steel plates, to form networks.
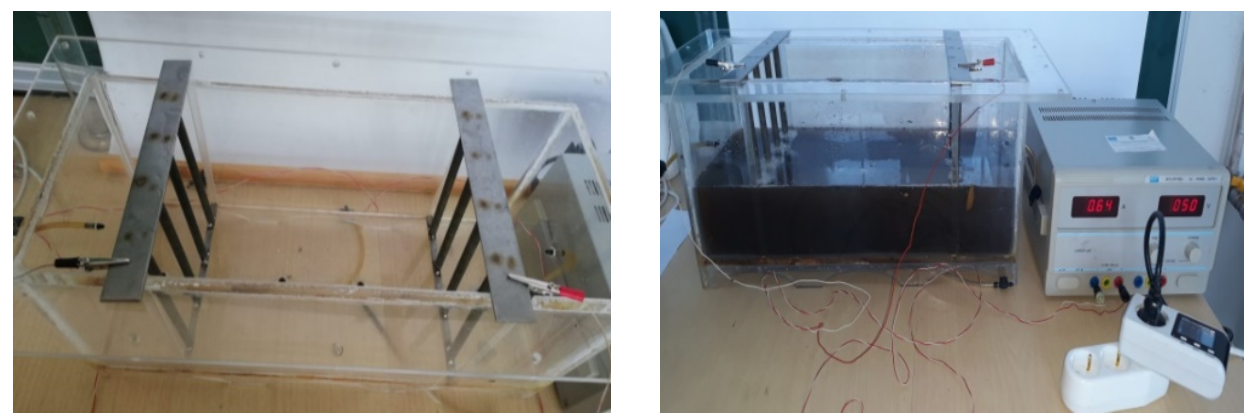

Fig. 3. Experimental setup for wastewater electrooxidation (stationary regime)

Current intensity is an important parameter that influences the efficiency of electrooxidation. As current intensity increases, the amount of anodic dissolution increases, hence an improved coagulation of pollutants will occur. In this test, different specific voltages were applied: $0.025 \mathrm{~V} \mathrm{~cm}^{-2}$ (test T1), $0.05 \mathrm{~V} \mathrm{~cm}^{-2}$ (test T2) and $0.1 \mathrm{~V} \mathrm{~cm}^{-2}$ (test T3) for a wastewater volume of 9 liters. During all tests it was maintained the same polarity of the electrodes, namely the positive electrode (anode) was on the right and the negative electrode (cathode) was on the left of the electrochemical cell. The evolution of wastewater treatment was observed by carrying out determinations at 15, 30, 60 and 120 minutes exposure times. Raw wastewater and samples of wastewater treated by each electrooxidation test (taken from the middle distance between the electrodes) were analyzed to determine if they comply with the existing regulations regarding the use of wastewater for irrigation of agricultural crops.

Conventional quality parameters associated with wastewater treatment include $\mathrm{pH}$, conductivity, color, turbidity, total $\mathrm{N}$, total $\mathrm{P}, \mathrm{COD}$ and $\mathrm{BOD}$, which were analyzed according to the methods mentioned by the Romanian norms corresponding to the standard in force regarding the establishment of pollutant loading limits for industrial and urban wastewater (NTPA-001/2002 and NTPA-002/2002). Among the analyzed parameters, the 
Romanian STAS 9450-88 imposes limits for $\mathrm{pH}$, electrical conductivity and total nitrogen, dividing the waters by quality classes. The aim of this study was to reduce pollutant loads and to assess if the effluent can be used for crop irrigation in arid and semiarid areas.

\section{Results and discussion}

Table 1 presents the characteristics of raw wastewater, which has high content of nitrogen and phosphorus. Raw wastewater has relatively small percentage of biodegradable organic compounds (expressed as biochemical oxygen demand, BOD) compared to the total content of organic substances (expressed as chemical oxygen demand, COD) in wastewater, due to the oxidation of the organic matter mainly by exposure to the external environmental conditions in the lagoon where the wastewater was kept for a long time.

Table 1. Initial characteristics of raw wastewater (control sample)

\begin{tabular}{|c|c|c|c|}
\hline Parameter & Value & Parameter & Value \\
\hline $\mathrm{pH}$ (units) & 7.80 & Total $\left.\mathrm{mg} \mathrm{L}^{-1}\right)$ & 234.2 \\
\hline Conductivity (mS cm & -1 \\
\hline Color $(\mathrm{HZ})$ & 3.84 & Total $\mathrm{P}\left(\mathrm{mg} \mathrm{L}^{-1}\right)$ & 56.4 \\
\hline Turbidity (NTU) & 1092 & $\mathrm{COD}\left(\mathrm{mg} \mathrm{O}_{2} \mathrm{~L}^{-1}\right)$ & 1512.6 \\
\hline & 724 & $\mathrm{BOD}\left(\mathrm{mg} \mathrm{O}_{2} \mathrm{~L}^{-1}\right)$ & 204.5 \\
\hline
\end{tabular}

The physico-chemical parameters of farm wastewater following different electrooxidation treatment are presented in Table 2.

Table 2. Physico-chemical characteristics of wastewater after electrooxidation

\begin{tabular}{|c|c|c|c|c|}
\hline Test_time & $\mathrm{pH}$ & $\begin{array}{c}\text { Conductivity } \\
\left(\mathrm{mS} \mathrm{cm}^{-1}\right)\end{array}$ & $\begin{array}{c}\text { Color } \\
(\mathrm{HZ})\end{array}$ & $\begin{array}{c}\text { Turbidity } \\
(\mathrm{NTU})\end{array}$ \\
\hline T1_15 & 7.84 & 3.86 & 1054 & 571 \\
\hline T1_30 & 7.84 & 3.86 & 1069 & 576 \\
\hline T1_60 & 7.86 & 3.84 & 1093 & 636 \\
\hline T1_120 & 8.14 & 3.81 & 1111 & 645 \\
\hline T2_15 & 7.96 & 3.85 & 980 & 542 \\
\hline T2_30 & 8.02 & 3.83 & 1043 & 576 \\
\hline T2_60 & 8.01 & 3.76 & 1134 & 656 \\
\hline T2_120 & 8.36 & 3.71 & 1145 & 736 \\
\hline T3_15 & 7.96 & 3.82 & 1139 & 644 \\
\hline T3_30 & 7.99 & 3.77 & 1176 & 708 \\
\hline T3_60 & 8.00 & 3.74 & 1167 & 744 \\
\hline T3_120 & 8.20 & 3.60 & 1180 & 770 \\
\hline Test_time & Total N & Total P & COD & BOD \\
\hline T1 L L $\left.^{-1}\right)$ & $\left(\mathrm{mg} \mathrm{L}^{-1}\right)$ & $\left(\mathrm{mg} \mathrm{O}_{2} \mathrm{~L}^{-1}\right)$ & $\left(\mathrm{mg} \mathrm{O}_{2} \mathrm{~L}^{-1}\right)$ \\
\hline T1_30 & 202.7 & 47.3 & 816.6 & 102 \\
\hline T1_60 & 201.3 & 49.3 & 770.2 & 89.9 \\
\hline T1_120 & 207.5 & 47.5 & 779.5 & 86.7 \\
\hline T2_15 & 200.4 & 44.2 & 705.3 & 74.3 \\
\hline T2_30 & 204.6 & 44.2 & 700.6 & 93.6 \\
\hline T2_60 & 205.5 & 44.5 & 668.2 & 97.5 \\
\hline T2_120 & 178.5 & 43.1 & 626.4 & 55.9 \\
\hline T3_15 & 212.5 & 48.3 & 626.4 & 36.5 \\
\hline T3_30 & 201 & 45.1 & 730.3 & 67.6 \\
\hline T3_60 & 208.9 & 43.1 & 663.5 & 57.6 \\
\hline T3_120 & 193.1 & 30.0 & 607.8 & 42.8 \\
\hline & & & & \\
\hline & & & 756.3 & 67.7 \\
\hline
\end{tabular}


Analyzing the data in Table 2 compared with those in Table 1, it can be observed that in all three sets of tests, the values obtained for $\mathrm{pH}$, conductivity, color, turbidity, total nitrogen and total phosphorus did not change significantly. In contrast, for some samples, the chemical oxygen demand was reduced by half, and the biochemical oxygen demand was reduced by almost 5 times.

The results were plotted as a function of treatment time, as shown in Figures 4-7.

From the analysis of the $\mathrm{pH}$ of the treated wastewater samples (Figure 4) it can be observed that regardless of the specific voltage applied to the electrodes and the duration of treatment, when compared to the control sample, there were no significant differences in $\mathrm{pH}$. All samples of wastewater treated by electrooxidation had alkaline $\mathrm{pH}$, the values increasing slightly with the duration of treatment; the highest $\mathrm{pH}$ values were recorded for the treatment time of 120 minutes.

According to the Romanian STAS 9450-88, the samples of treated wastewater are weakly alkaline ( $<8.6$ units) and are accepted for use as irrigation water. If the $\mathrm{pH}$ exceeds 8.6 units, secondary soil degradation processes would occur.

The electrical conductivity of the treated water had a decreasing tendency over time, without significant differences between the values recorded for the three specific voltages. In terms of conductivity, with respect to STAS 9450-88, in all tests, the treated water falls in salinity class C3 - it has high saline residue, so the water it can be applied on permeable soils and for irrigation of salinity tolerant crops.

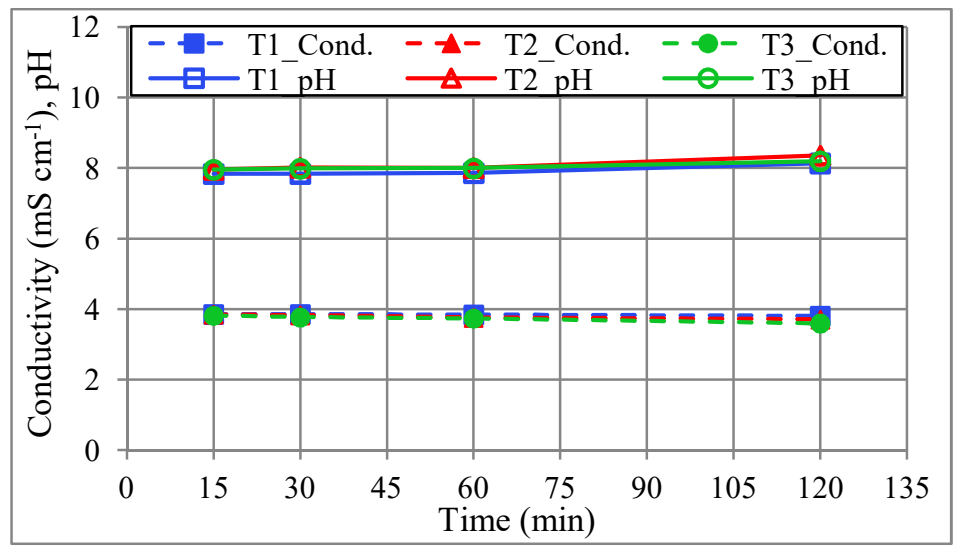

Fig. 4. Variation of $\mathrm{pH}$ and conductivity during testing $\left(\mathrm{T} 1=0.025 \mathrm{~V} \mathrm{~cm}^{-2} ; \mathrm{T} 2=0.05 \mathrm{~V} \mathrm{~cm}^{-2} ; \mathrm{T} 3=\right.$ $0.1 \mathrm{~V} \mathrm{~cm}^{-2}$ )

Regarding Figure 5, although it is not a standardized parameter, wastewater color influences indirectly the possibility of reuse because color is given by the concentrations of suspended solids and dissolved substances that can cause malfunctioning of the irrigation systems.

The color of treated water changed visibly between tests 2 and 3, due to air bubbles created in the electrooxidation cell, which entrained the solid matter, and to electrode dissolution which released Fe ions into the water; thus, after the last test, the formed foam was reddish. Wastewater turbidity is given by the presence of colloidal species, suspended solids and microorganisms. During each test, the turbidity increased with increasing treatment time, but in the first two tests there were lower values compared to the control sample. 


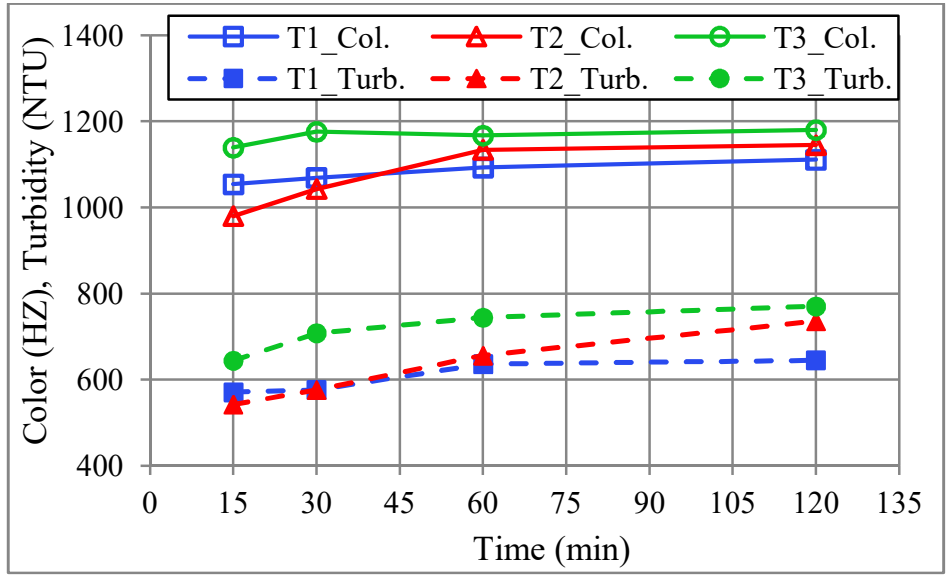

Fig. 5. Variation of color and turbidity during testing $\left(\mathrm{T} 1=0.025 \mathrm{~V} \mathrm{~cm}^{-2} ; \mathrm{T} 2=0.05 \mathrm{~V} \mathrm{~cm}^{-2} ; \mathrm{T} 3=0.1\right.$ $\mathrm{V} \mathrm{cm}^{-2}$ )

Nitrogen is a common pollutant in agricultural waters as a result of the use of chemical fertilizers. Phosphorus is found in chemical fertilizers and detergents, so it is contained in domestic wastewater and in wastewater from washing the milking and dairy factory equipment within the farm. The variation in time of these nutrients is given in Figure 6. Compared to the control sample, at maximum exposure time, highest removal of total N (24 $\%$ ) was achieved in test 2 (specific voltage of $0.025 \mathrm{~V} \mathrm{~cm}^{-2}$ ), while for total $\mathrm{P}$ the highest removal efficiency of $47 \%$ was obtained in test 3 (at $0.1 \mathrm{~V} \mathrm{~cm}^{-2}$ ). According to STAS $9450-88$, the values of total nitrogen fall into class C3, is usable on permeable soils and for irrigation of salinity tolerant crops.

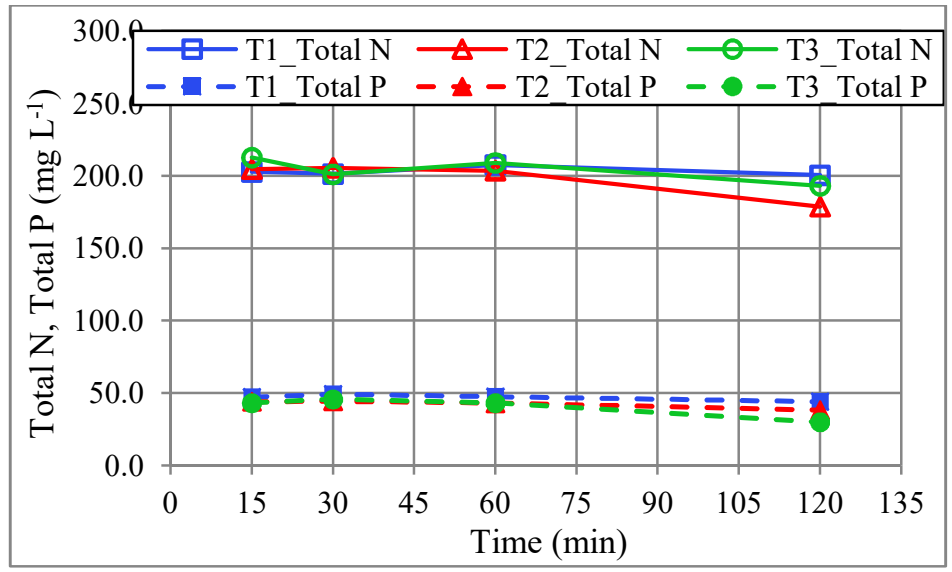

Fig. 6. Variation of total $\mathrm{N}$ and total $\mathrm{P}$ during testing $\left(\mathrm{T} 1=0.025 \mathrm{~V} \mathrm{~cm}^{-2} ; \mathrm{T} 2=0.05 \mathrm{~V} \mathrm{~cm}^{-2} ; \mathrm{T} 3=0.1\right.$ $\mathrm{V} \mathrm{cm}^{-2}$ )

The concentration of organic compounds in wastewater is assessed by the chemical oxygen demand (COD) and biochemical oxygen demand (BOD), parameters by which the degrees of chemical and biochemical oxidability are estimated. Analyzing the variations in Figure 7, compared to the control sample, after 120 minutes, BOD removal rates were $64 \%$ at specific voltage of $0.025 \mathrm{~V} \mathrm{~cm}^{-2}, 82 \%$ at $0.05 \mathrm{~V} \mathrm{~cm}^{-2}$ and $79 \%$ at $0.1 \mathrm{~V} \mathrm{~cm}^{-2}$. The electrooxidation treatments have also given good results in reducing the chemical oxygen 
demand (COD) thus: $47 \%$ at $0.025 \mathrm{~V} \mathrm{~cm}^{-2}, 41 \%$ at $0.05 \mathrm{~V} \mathrm{~cm}^{-2}$, respectively $40 \%$ at $0.1 \mathrm{~V}$ $\mathrm{cm}^{-2}$.

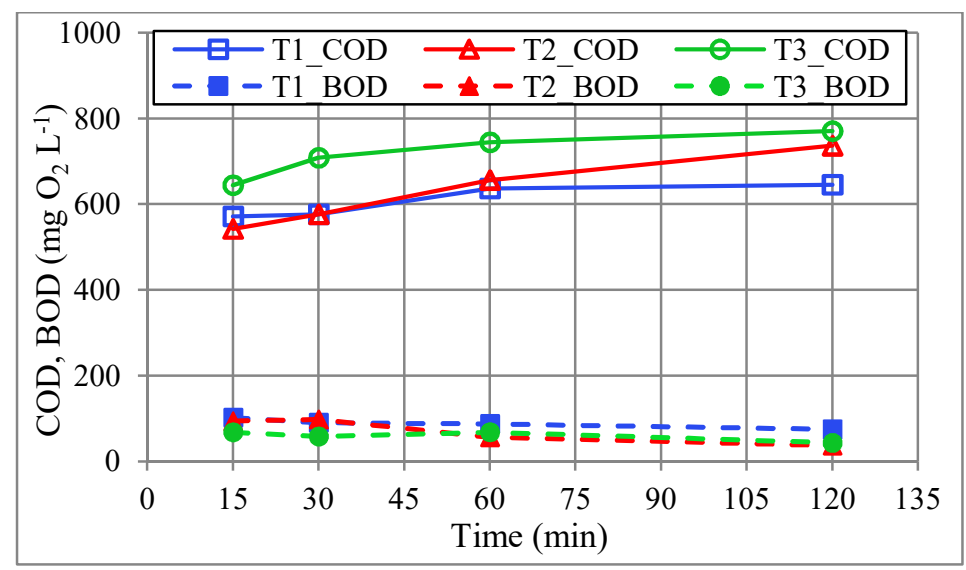

Fig. 7. Variation of COD and BOD during testing $\left(\mathrm{T} 1=0.025 \mathrm{~V} \mathrm{~cm}^{-2} ; \mathrm{T} 2=0.05 \mathrm{~V} \mathrm{~cm}^{-2} ; \mathrm{T} 3=0.1 \mathrm{~V}\right.$ $\mathrm{cm}^{-2}$ )

Regarding the reaction of wastewater subjected to an electric field, at first there was a more intense activity in the cathode area, which towards the end of the tests moved to the anode area (Figure 8), where intense foaming occurred. Foaming shows the formation of gas $\left(\mathrm{O}_{2}\right.$ and $\left.\mathrm{Cl}_{2}\right)$ at the anode. There was no important release of $\mathrm{H}_{2}$ at the cathode because some of the electrons were transferred by the discharge of metal ions that reentered the solution, as soluble metal hydroxide, which led to a slight increase in wastewater $\mathrm{pH}$. This concurrent reaction to the classical reaction of water electrolysis with the formation of $\mathrm{H}_{2}$ has consequently resulted in slowing of $\mathrm{H}_{2}$ emissions at the cathode.
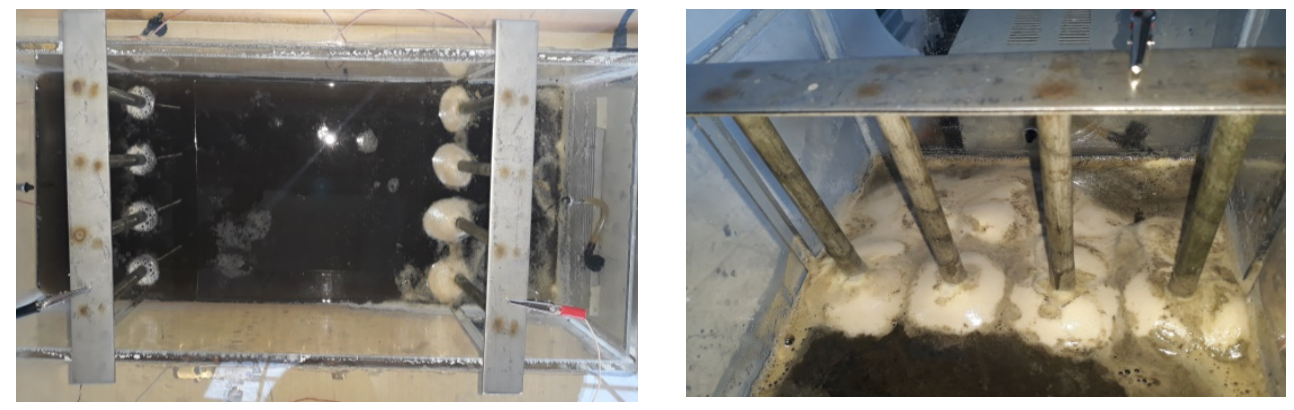

Fig. 8. Intense foaming at the anode during testing

After completion of the tests, the treated wastewater had reddish color due to the dissolution of $\mathrm{Fe}$ ions in the electrode material. After being left idle for 24 hours in the electrochemical cell, it was observed that the suspended solids in the water have decanted at the base of the electrochemical cell towards the anode area in a thick layer of about $2 \mathrm{~cm}$, while the water cleared (Figure 9).

Sludge formation is explained by the action of $\mathrm{Fe}^{2+} / \mathrm{Fe}^{3+}$ ions that are formed by anode dissolution and which act as a coagulant on the dissolved substances and the suspended matter. In addition to $\mathrm{O}_{2}$ and $\mathrm{Cl}_{2}$ near the anode, there are other reactive oxygen species $\left(\mathrm{H}_{2} \mathrm{O}_{2}, \mathrm{O}_{3}, \mathrm{OH} \cdot\right)$ and reactive chlorine species (hypochlorite, $\left.\mathrm{Cl} \cdot\right)$ that play a role in the oxidation of pollutants. 

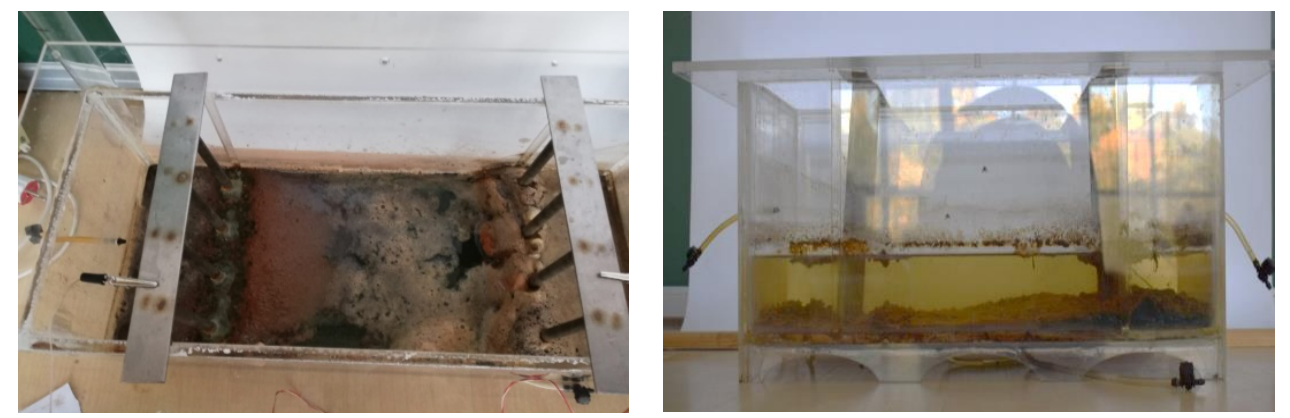

Fig. 9. Water after finalizing the tests, respectively clarification by decanting of suspended matter 24 hours after testing

The existence in the same cell of electrooxidation of the anodic and cathodic environment facilitates the production of secondary reactions between the metal hydroxide and $\mathrm{Cl}_{2}$ with the formation of chlorates which in turn have an oxidizing effect.

\section{Conclusions}

Wastewater from cattle farm was treated by electrooxidation using different specific voltages $\left(0.025 \mathrm{~V} \mathrm{~cm}^{-2}, 0.05 \mathrm{~V} \mathrm{~cm}^{-2}\right.$ and $\left.0.1 \mathrm{~V} \mathrm{~cm}^{-2}\right)$, aiming to reduce the loads of physicochemical pollutants. The most important removal efficiencies were: $82 \%$ for biochemical oxygen demand, $47 \%$ for chemical oxygen demand, $47 \%$ for total phosphorous and $24 \%$ for total nitrogen.

However, close values of water quality parameters between tests prove that higher energy consumption (test 3) is not technically-economically reliable. Establishing the optimum conditions for the treatment of wastewater is mandatory to avoid the increase of the temperature in the electrooxidation cell with the increase of intensity of the electric current or to avoid the consumption of anode by its excessive dissolution.

Electrooxidation can be efficient for the treatment of wastewater from the cattle farms, and its efficiency could be increased by coupling of electrooxidation with other treatments, including disinfection, for the safe reuse as irrigation water in Romania.

This work was supported by a grant of the Romanian Ministry of Research and Innovation CCDI UEFISCDI, Project INNOVATIVE TECHNOLOGIES FOR IRRIGATION OF AGRICULTURAL CROPS IN ARID, SEMIARID AND SUBHUMID-DRY CLIMATE, project number PN-III-P1-1.2PCCDI-2017-0254, Contract no. 27 PCCDI / 2018, within PNCDI III.

\section{References}

1. European Commission, Environment, Water Scarcity \& Droughts in the European Union (2019), https://ec.europa.eu/environment/water/quantity/scarcity_en.htm

2. Food and Agriculture Organization of the United Nations, How to Feed the World in 2050 http://www.fao.org/fileadmin/templates/wsfs/docs/expert_paper/How_to_Feed_the_W orld_in_2050.pdf

3. F. Pedrero, I. Kalavrouziotis, J.J. Alarcón, P. Koukoulakis, T. Asano, Use of treated municipal wastewater in irrigated agriculture - review of some practices in Spain and Greece, Agricultural Water Management 97: 1233-1241 (2010) 
4. European Commision, Environment, Water Reuse https://ec.europa.eu/environment/water/reuse.htm

5. Z. Ujang, M. Henze, Municipal wastewater management in developing countries, IWA Publishing (2006)

6. C. Becerra - Castro, A.R. Lopes, I. Vaz-Moreira, E.F. Silva, C.M. Manaia, O.C. Nunes, Wastewater reuse in irrigation: a microbiological perspective on implications in soil fertility and human and environmental health, Environment International 75: 117135 (2015)

7. T.E.S. Santos, R.S. Silva, C.T. Meneses, C.A. Martínez-Huitle, K.I.B. Eguiluz, G.R. Salazar-Banda, Unexpected enhancement of electrocatalytic nature of $\mathrm{Ti} /$ $\left(\mathrm{RuO}_{2}\right) \mathrm{xe}\left(\mathrm{Sb}_{2} \mathrm{O}_{5}\right) \mathrm{y}$ anodes prepared by ionic liquid-thermal decomposition method, Industrial \& Engineering Chemistry Research 55: 3182-3187 (2016)

8. I. Chakchouk, N. Elloumi, C. Belaid, S. Mseddi, L. Chaari, M. Kallel, A combined electrocoagulation-electrooxidation treatment for dairy wastewater, Brazilian Journal of Chemical Engineering 34 (1): 109-117 (2017)

9. D. Moussa, M. El-Naas, M. Nasser, M. Al-Marri, A comprehensive review of electrocoagulation for water treatment: potentials and challenges, Journal of Environmental Management 186 (1): 24-41 (2017)

10. S. Garcia-Segura, Ocon J.D., M.N. Chong, Electrochemical oxidation remediation of real wastewater effluents - a review, Process Safety and Environmental Protection 113: 48-67 (2018)

11. J.M. Aquino, G.F. Pereira, R.C. Rocha-Filho, N. Bocchi, S.R. Biaggio, Electrochemical degradation of a real textile effluent using boron-doped diamond or $\beta$ $\mathrm{PbO}_{2}$ as anode, Journal of Hazardous Materials 192 (3): 1275-1282 (2011)

12. K. Bensadok, N. El Hanafi, F. Lapicque, Electrochemical treatment of dairy effluent using combined $\mathrm{Al}$ and Ti/Pt electrodes system, Desalination 280: 244-251 (2011)

13. M. Changmai, M. Pasawan, M.K. Purkait, Treatment of oily wastewater from drilling site using electrocoagulation followed by microfiltration, Separation and Purification Technology 210: 463-472 (2019)

14. G. Hasani, A. Maleki, H. Daraei, R. Ghanbari, M. Safari, G. McKay, K. Yetilmezsoy, F. Ilhan, N. Marzban, A comparative optimization and performance analysis of four different electrocoagulation-flotation processes for humic acid removal from aqueous solutions, Process Safety and Environmental Protection 121: 103-117 (2019)

15. A. Dimoglo, P. Sevim-Elibol, O. Dinç, K. Gökmen, H. Erdoğan, Electrocoagulation / electroflotation as a combined process for the laundry wastewater purification and reuse, Journal of Water Process Engineering 31, 100877 (2019) 